\title{
Is T.T. Cloete 'n Calvinistiese digter?
}

\author{
B.J. Odendaal \\ Departement Afrikaans en Nederlands \\ Universiteit van die Oranje-Vrystaat \\ BLOEMFONTEIN
}

\begin{abstract}
Is T.T. Cloete a Calvinist poet?

T.T. Cloete has had a strong influence on contemporary Afrikaans poetry, particularly as a religious poet with a fanerotic world view. Some critics have characterized him as a Calvinist poet, and the validity of such a description is discussed in this article.

It is pointed out that Cloete's Biblical orientation as well as the importance given to the so-called general or creational revelation of God in his poetry, is typically Calvinist. The panentheistic trend in his view of the relation between God and cosmos, the aesthetic mysticism that distinguishes his experience of God and the consequent discomfort in his poems about the meaningfulness of death in the dispensation of God, are, however, indicated as motives deviating from a typically Calvinist world view. In these respects his views, as expressed in his poetry, show similarities with those of the Catholic tradition, even with those of the Eastern Christian church.
\end{abstract}

\section{Inleidend}

Sedert die verrassendel verskyning van sy debuutbundel Angelliera in 1980 het T.T. Cloete 'n groot impak op die Afrikaanse literêre wêreld gehad. Hiervan getuig byvoorbeeld die feit dat byna elke belangrike Afrikaanse literêre prys sommige by herhaling - sedertdien aan hom toegeken is. ${ }^{2}$

Ook spesifiek as religieuse digter was sy invloed deurslaggewend. Waar daar in 1980 die opinie uitgespreek is dat 'n "genadelose bevraagtekening van die Bybel" (Olivier, 1980:26) in (onder meer) die Afrikaanse poësie in die vooruitsig gestel

1 In sy keurdersverslag (opgeneem in Botha, 1991:41-42) skryf D.J. Opperman op 13 Julie 1980 oor dié bundel (toe nog met die titel Van heinde en ver) dat dit "die letterkundige nuus van die jaar" gaan word, en dat dit "een van die grootste verrassings in ons letterkunde" is

2 Vergelyk die spesiale uitgawe van literator (1995, 16/3, November), opgedra aan T.T. Cloete, Bylaag 1: Toekennings, p. 10. 
kon word, het Spies in 1984 (p. 25) en Bosman in 1989 (p. 7 e.v.) daarop gewys dat die religieuse tendens in die Afrikaanse digkuns sedert die sewentigerjare nie getaan het nie, maar eerder gegroei het. Dié groei het gepaard gegaan met wat Spies (1984:25) tipeer as 'n "grondverskuıwing" na groter gevoeligheid en 'n pertinenter persoonlike trant.

In hierdie ontwikkeling sou Cloete 'n leidende rol speel. Dit blyk eerstens uit die kritiese werk wat oor sy digkuns geskryf is. Tot 1994 is byvoorbeeld minstens veertien verhandelings en proefskrifte oor sy werk voltoo ${ }^{3}$, waarvan die helfte spesifiek oor religieuse temas en tendense in sy poësie handel. Ook het sy poësie 'n opvallende invloed gehad op die kreatiewe werk van 'n aantal jonger Afrikaanse digters wat digkuns met 'n opvallende religieuse inhoud gelewer het. ${ }^{4}$

\section{Cloete as religieuse digter}

H.G. Stoker (1967:65), een van die belangrikste Calvinistiese wysgere wat ons land opgelewer het, onderskei religie van godsdiens in enger sin as 'n dien van God waar die mens sy roeping tot die eer en verheerliking van God vervul en God gehoorsaam in alles wat hy doen en laat: die wêreld beheers, kultuur skep, geskiedenis vorm, al die moontlikhede van die skepping aktualiseer.

Waar Cloete se poësie 'n poging is om die "whole of experience in all its baffling complexity" (Glicksberg, 1977:61) onder woorde te bring, kan dit dus in hierdie sin as ware religieuse digkuns bestempel word. Die sentrale tema of sluitmotief daarvan is die kosmiese Godsopenbaringe, oftewel die wyse waarop die "deurlopende multimultimeervoud" ("ubiquiteit", I:1335) van die skeppingsdinge en -ervarings die bestaan en werksaamheid van God die Skepper uitdruk.

3 Kyk Bylaag 2 tot genoemde spesiale uitgawe van Literator, p. 11-12.

4 In haar resensie oor Johan Myburg se Kontrafak skryf Joan Hambidge (1995:37) byvoorbeeld: "By Johan Myburg (...) is die stem wat deur al die gedigte fluister, T.T. Cloete Nou kan Cloete se invloed nie langer ontken word nie; selfs in Daniel Hugo se Dooiemansdeur en Antjie Krog se Jerusalemgangers is hy dáar." Twee digters wie se werk opvallend met dié van Cloete verbind is, is Tom Gouws en Johan Myburg (Vergelyk onder meer Grové, 1995:32; Lindenberg, 1995:116; Hambidge, 1995:37, Van Zuydam, 1995:8, Odendaal, 1995:8.)

5 In dié artikel sal die volgende afkortings gebruik word om na die sestal verskene bundels van Cloete te verwys: $A=$ Angelliera (1980), $J=J$ ukstaposisie $(1982, A l=$ Allotroop (1985), $I=I$ Idiolek (1986), $D=$ Driepas (1989) en Mdap $=$ Met die aarde praat (1992). Dic syfers ná die dubbelpunt wat op die afkortings volg, is bladsyverwysings 


\section{Die fanerotiese werklikheidsbeskouing van Cloete}

In 'n onderhoud met die SWO BULLETIN (1993a:6-7) verklaar Cloete: "Vir my as ontdekker van die werklikheid van alles binne en buite jou so ver jy dit kan belewe, is dit onvermydelik dat ek sal glo in die bestaan van 'n Goddelike skepper. Ek het met baie teoloë gepraat. Hulle sê vir jou daar is nie Godsbewyse nie. Ek sê daar ís Godsbewyse. En dan antwoord hulle ja, vir dié wat reeds glo."

Hy vind die Godsbewyse in bepaalde vorme en wetmatighede wat hy in die skepping waarneem - "konkrete idees" in die skepping wat hom boei, soos hy dit by 'n ander geleentheid gestel het (Cloete, 1993b:7-8). Hy verwys na strukture soos die spiraal en die heksagoon wat in uiteenlopende skeppingsdinge herhaal word, en na verskynsels soos jukstaponering, mimikrie en entelegie, maar ook na wat hy "bontheid" in die skeppingsdinge noem (Cloete, 1993b:8-11).

In 'n artikel waarin hy die wyse nagaan waarop Cloete fenomene in sy poësie hanteer, kom Viljoen (1995a:43-59) tot die gevolgtrekking dat daar verbande is tussen Cloete se poësie en Husserl se Fenomenologie. Hy gaan vier aspekte van Cloete se kyk op die werklikheid na: eerstens die "geleerde, universele soort sien" (Viljoen, 1995a:47), wat in Cloete se eie terne ook die "versamelsien" genoem kan word; tweedens die "raaksien van korrespondensies" (Viljoen, 1995a:47); derdens die kyk met die sogenaamde "deologiese oog" (Viljoen, 1995a:51-52) waarmee oral in die skepping rondom die mens "spore, tekens of 'insinjes' van God" waargeneem word; en laastens die kyk met die "refleksiewe" en "selfrefleksiewe" oog (Viljoen, 1995a:54-58), naamlik die raaksien van hoe die een fenomeen hom in die ander herken, maar wat dan eintlik 'n projeksie van die waanemende subjek se bewussyn verteenwoordig.

Viljoen wys egter ook op die wyse waarop 'n woord soos "transendentaal" (J:57; I:39) 'n wye resonansie by Cloete kry; die wyse waarop die verskynsels hulle betekenis eintlik eers in Cloete se poësie kry "in die transendentale ruimte wanneer hulle presiese plek en tyd nie in die gewone tyd en ruimte nie maar in God se orde bepaal is" (Viljoen, 1995a:58). Besonderhede aangaande die fenomene - byvoorbeeld "toevallighede" van tyd en plek - word volgens hom deur Cloete uitgeëssensialiseer (fenomenologiese reduksie). Die dinge verskyn in 'n "ideaal-logiese dimensie", waar hul "universele logiese wese" raakgesien word (eidetiese reduksie).

Hierdie logiese wese is, skryf Viljoen (1995a:58) ten slotte, "'n kennis van God" Dié laaste opmerking van Viljoen maak dit myns insiens duidelik dat om van 'n fenomenologiese kyk by Cloete te praat, nie heeltemal bevredig nie. 'n Mens sou cerder van 'n fanerotiese blik op die kosmos moet praat, dit wil sê die sien of insien van die Goddelike openbaringsinhoud van Woord én Skepping "hier by ons, op kreatuurlike wyse in die skepping of geskape kosmos", en wel "kragtens 
die kenbaarheid van die kosmos en die ken-aanleg van die mens, wat albei hul oorsprong in God vind" (Stoker, 1970:241). Die skeppingsdinge is "teofanies" van aard "vir die deoloog", soos dit in die tweede gedig van sy oeuvre heet ("Suidpool en senit I", $A: 2$ ), dit wil sê dit word as Godsverskyninge deur die God-kundige waargeneem

Die fanerotiese kyk laat Cloete, hoewel hy strewe om die volle werklikheid onder oë te neem (Cloete, 1993b:17), tog by voorkeur - of liewer: onvermydelik bepaalde verskynsels of kante van verskynsels, asook bepaalde "wetmatighede" raaksien. Die neiging tot "versamelsien" en om die korrespondensies tussen uiteenlopende verskynsels raak te sien, is byvoorbeeld reeds genoem. Dit hang saam met die oortuiging dat alles deur 'n enkele oppermagtige Skepper in aansyn geroep is, en dus wetmatighede en samehang sal/moet vertoon.

By geleentheid het Cloete (1993b:8) gevra-sê dat hy in sy poësie nie uitgepraat kan raak oor die goeie, mooie en wonderbaarlike nie. Dit moet in samehang gesien word met 'n ander geleentheid (Cloete, 1991:33-34) toe hy kritiek uitgespreek het teen die geneigdheid by sekere skrywers en kritici "om die 'problematiese', die ellendige, die omstredene as voorkeurmateriaal of -veld vir die skrywer uit te kies", gepaardgaande "met die oortuiging dat die literatuur die wêreld ingrypend en dramaties kan verbeter, dat dit met ander woorde 'n pragmatiese instrument is". In sy bespreking van die aktualiteitsvers in Cloete se eerste twee bundels, het Visagie (1986:151-159) dan ook gevind dat daar geen sprake is van direkte politieke betrokkenheid in Cloete se verse nie ${ }^{6}$. Hy skryf (Visagie, 1986:159): "Dit is duidelik dat Cloete in sy aktualiteitsgedigte die algemeen-menslike wil uitbeeld en nié die spesifiek Suid-Afrikaanse maatskaplike en politieke toestande van vandag nie."

6 Dit bly hoofsaaklik die bevinding indien die res van sy oeuvre hiervoor gefynkam word. Daar is 'n verwysing na "'n nasionale skuld en gewete" waaraan die nakomelinge van Jan van Riebeeck ly ("modifikasie: má vlast", $A l: 93$ ); die heterogeniteit van die kulture in Suid-Afrika word aangesny of deur middel van die opnoem van plekname gedemonstreer ("Allofonie", Al:94; "Land van die eggo's", $D: 119-120$ ), die stereotiepe verering van Afrikanervoorgeslagte wórd by geleentheid ontdoen ("Foto Boerevegters", $D: 11$ ); daar is 'n satirisering van die banaliteite en ironieë rondom verkiesings en grondwetlike hervorming in die Suid-Afrika van die tagtigerjare ( $D: 112$ 114); en daar ís sinspelings op die uiteindelike ontmagtiging en selfs vernietiging van die ideologies verstarde en Eurosentriese Afrikaner of "Europide tipe" (D:116-117 en $J: 82$ ). Dié gedigte maak egter so 'n minderheid uit in sy oeuvre dat 'n mens skaars sou kon praat van politieke betrokkenheid in die sin wat Visagie in sy verhandeling beskryf het, naamlik as kritikus van die vorige Suid-Afrikaanse regeringsbeleid. 
Cloete werp 'n universele, fanerotiese blik op die kosmos. Om hierdie rede is sy blik nie skerp ingestel op die "toevallighede" van plek en tyd nie (soos Viljoen uitgewys het), veral nie as die betekenisinhoud daarvan nie duidelik Godopenbarend van aard is nie.

'n Deel van die fanerotiese perspektief in Cloete se poësie behels die beskouing van alle verskynsels as tuisgebring binne die Goddelike skeppingsplan. Binne die Raadsplan van die Groot Beweger, die "Primum en Perpetuum Mobile" ("Mercury", 1:87), het elke ding syns insiens sy plek en doel, word elke minuskule deeltjie van die kosmos "heel in alle gedaantes van die ewige geheel" ("Herbenutting", $A: 3$ ). 'n Aantal kere is daar eksplisiete verwysings na die Raadsplan of Wil van God $(A: 11,33,59 ; J: 108 ; M d a p: 73)$, of suggesties dat in Hom uiteindelik alles sinvol is $(J: 34 ; A l: 12 ; D: 179)$. Ook die oënskynlik nuttelose en doellose, en selfs die bose en duiwelse word gepositiveer deur daarvoor 'n plek en doel binne die Goddelike Raadsplan te vind.

\section{Is Cloete 'n Calvinistiese digter?}

Dat Cloete se beskouings soos gemanifesteer in sy digkuns dus fundamenteel Christelik-gelowig van aard is, is onmiskenbaar. Sommige kommentatore op sy werk (onder meer Potgieter, 1988; Bosman, 1989; Jansen van Rensburg, 1990) het dié beskoulike raamwerk egter as spesifiek Christelik-Reformatories of Calvinisties ${ }^{7}$ getipeer.

\subsection{Tipiese Calvinistiese motiewe in sy verskuns}

\subsection{1 'n Bybelse begronding}

In die Calvinistiese leer, soos in alle Reformatoriese belydenisse, geld wat Jonker (1994:28) die "primaat van die Woord van God" genoem het. Die Skrif is die norm waar dit beskoulike aangeleenthede betref; dit is "the rule of faith (which guides [the Calvinist's] intellect) and practice (which determines his daily duty)" (Meeter, 1975:41 - sy kursivering). Ook toon Jonker (1994:43) aan dat dit van belang is om daarop te let dat die Ou Testament in (wat hy noem) die

7 Die term "gereformeerd" word by voorkeur deur iemand soos Jonker (1994) gebruik om na die teologiese beskouings in die Calvinistiese tradisie te verwys. Stoker (1967:72-73) redeneer dat "Reformatories" of "Protestants" 'n te wye betekenis het en ook ander Protestantse en Reformatoriese lewens- en wêreldbeskouings (kan) insluit, terwyl "gereformeerd" syns insiens "tot kerk en godsdiens beperk" is. Hy verkies die aanwysing "Calvinisties" omdat dit volgens hom die histories geykte onderskeidingsteken is van die suiwerste en konsekwentste Hervormingsbelydenis. In hierdie artikel sal die term ('alvinisties deurgaans gebruik word. 
"gereformeerde tradisie" as van besondere gewig beskou word, meer as in byvoorbeeld die Anabaptistiese en Lutherse tradisies.

Soos onder meer Bosman (1989:291-292) beklemtoon het, is die poèsie van Cloete "voortdurend ingestem" op die Bybel: "Telkens is daar verwysing na, omdigting van, kommentaar op Skrifgedeeltes (Job, Psalms, Prediker, Jesaja, Johannes ...) en vereenselwiging met Bybelse figure: Hiskia, veral Job ...". Cloete se geloof soos dit in sy verse tot uitdrukking kom, bevat trouens iets OuTestamenties. Daar is byvoorbeeld relatief min eksplisiete verwysings na Jesus Christus en geen verwysing na die Heilige Gees in sy poësie nie, terwyl daar tog 'n baie groot aantal kere met 'n verskeidenheid benamings van God gewag gemaak word. Ook is die groot aantal Bybelse verwysings merendeels op die $\mathrm{Ou}$ Testament gerig.

Dit is God die Vader wat in sy verskuns sentraal staan, die Skepper, Onderhouer en Bestierder van hemel en aarde, hoewel die verwoording van die genadige bemoeiing van God met die mens in vreugde én pyn tog van 'n bewussyn van die soenverdienste van Christus en die werking van die Heilige Gees getuig.

\subsubsection{Die belang van die skeppingsopenbaring van God}

Gepaard met hierdie fokus op die Skeppers-, Onderhouers- en Bestierdersrol van God Drie-enig gaan die besondere klem wat Cloete plaas op die skeppings- of kosmiese openbaring van God, die sogenaamde algemene openbaring of die openbaring deur Gods werke. Dié wyse van die Goddelike openbaring kry in die Calvinistiese beskouings sy besliste plek naas die vertroue op die besondere openbaring van God deur sy Woord 8

\subsubsection{Eenheid in verskeidenheid}

Stoker (1967:49-50) meen dat dit juis "kenmerkend" van die Calvinistiese lewens- en wêreldbeskouing is dat volle erkenning gegee word aan die radikale verskeidenheid in en van die kosmos, maar wat dan weens die feit dat dit Gods skeppingswerk is, veelvormig saamhang om 'n innige eenheid te vorm. Dit konstitueer volgens hom (Stoker, 1967:51) die "veelkleurige sinrykheid" van die skepping, maar openbaar in hoofsaak ook die "wonder" waarmee God, naas sy heerskappy deur sy wet, sy skepping regeer (Stoker, 1967:53).

8 Die Bybel is die "tweede openbaring van God", deur Hom gegee omdat die eerste. algemene openbaring in die skepping as gevolg van die sonde vervals en verduister geraak het Calvyn het geskryf dat die Bybel die bril is waardeur die gelowige mens die natuur beskou (Meeter, 1975:43) 
So belangrik is hierdie kosmiese eenheid-in-verskeidenheidsmotief in Cloete se verse dat sommige van die hele aantal kritici ${ }^{9}$ wat daaroor geskryf het, onder meer Pretorius (1981) en Jansen van Rensburg (1990), dit as die sentrale motief van sy poèsie benadruk het. Veral die jukstaposisie-fenomeen het sedert die verskyning van die bundel Jukstaposisie (1982) in hierdie verband baie aandag getrek $^{10}$, en dit is duidelik dat die ooreenskuiwing van disparaathede, die waarneming en vind van korrespondensies of die paradoksale saamval van uiteenlopende sake in die werklikheid, veral in die latere bundels (met name in Driepas en Met die aarde praat), prominent is.

Opponerend tot samehang staan verbandloosheid of chaos. Cloete (1993b:11) gebruik die term "bontheid" in hierdie verband. 'n Deel van die 'bontheid'opposisie is volgens hom die "gebreke" en selfs "foute" in die werklikheid, asook die "fragmentariese", "chaotiese" en "katastrofale" - die "gebrek aan sinvolle samehang, buite ons, en binne ons, onontkoombare dinge soos pyn, dood, aardbewings, oorstromings, droogte". Omdat hy in sy poësie die volle werklikheid wil ontgin, skryf hy in talle van sy gedigte in al ses bundels oor dusdanige dinge.

Maar - en hier sien 'n mens duidelik die werking van sy beskoulike raamwerk juis wanneer hy die "(b)ont droom" ( $D: 176)$ van die kosmos sien, wanneer hy hom "stuk-stuk verbeel/ aan die geheel" ("Stukwerk", $A: 46$ ), kom hy weer onder die indruk van die grootsheid en wonderbaarlikheid daarvan - kan hy weer "(d)aardie hand" (D:108) in dit alles gewaar.

Wat meer is: Ten spyte van die waarneming van die bontheid en selfs van die teenstrydighede in die werklikheid, word alles tog deur die gelowige Cloete in samehang gesien of afgerond"1, of deur die poëtiese tegniek en strewe saamgebind. Volgens hom "versamel die oog en die taal dit in een gedig ... Daar is foute, gebreke, tekortkominge en onvolmaakthede in die skepping, en hulle is poeties vrugbaar, asof die gedig herstel kan bewerk, ek self weet nie mooi hoe nie, miskien deurdat dit die aaklige eufories maak (as dit die regte term is) deur die klank, die ritme, die versvorm, die beeld ... deur die hele gedig, met sy

9 Waaronder Brink (1981), Nienaber (1983), Gräbe (1984), Schutte (1984), Jansen van Rensburg (1990) en Viljoen (1995a).

10 Cloete self (19936 8-9) meen dat dit meestal verkeerdelik bloot as "n "tegniek" in sy poësie geinterpreteer is, terwyl dit volgens hom 'n prominente "idee" is wat hy in die skepping gewaar.

11 Die ronde oog "is sy eie norm"! ( $\mathrm{Vgl}$ " $\mathrm{oog}^{\circ}$, Mdap 9.) 
behoefte aan volmaaktheid, al sou hy dit nie bereik nie" (Cloete, 1993b:11 kursivering deur Cloete).

Dit is dus juis die waarneming of gewaarwording van die verbandlose/ chaotiese/ onvolmaakte wat die drang na die korresponderende/ ordelike/ volmaakte stimuleer. Soos dit in die gedig "Breek" $(D: 164)$ heet:

Uit die gebreekte kan 'n vreemder volmaakter belewe

kom: die valk met die vlerk wat skeef wegstaan

weet pynlik meer van valkwees as die een wat sweef.

Die bene wat so soepel loop en onbewustelik gaan

weet minder van loop as die slepende grassiebeen

van die kind of die kiewiet of die sprinkaan.

Die volmaakte is kenbaar uit die onvolmaakte alleen.

Die kenmerkend Calvinistiese erkenning van die volle werklikheidsverskeidenheid, maar waarin dan 'n Skeppersopenbarende, veelvormige samehang te ontdek is, is dus oorvloedig in die Cloete-oeuvre teenwoordig. In aansluiting by wat Stoker (1967:53) 'n "roepingstaak" van die gereformeerde mens genoem het om "“in U lig' op alle terreine van die skepping" die Goddelik geopenbaarde wetsorde te ontdek, te formuleer en te stel, voel Cloete hom eintlik verplig om sowel die verskeidenheid as die eenheid in die verskeidenheid raak te sien: "Ek moet die Skepping nie enkelvoudig belewe nie, ek moet hom as 'n verskeidenheid belewe, en ek moet in hierdie verskeidenheid 'n eenheid probeer vind" (Cloete, 1988:1; aangehaal deur Jooste, 1995:118-119).

Inderdaad: “(The Calvinist's) acceptance of the knowledge of God and His revelation ultimately rests on faith" (Meeter, 1975:9).

\subsubsection{Die mens/digter as verkenner en vertolker van die Goddelike openbaringe in die skeppingsdinge}

Die mens word deur Cloete gesien as die medewerker of hulp van God - of in algemeen-Christelike (d.w.s. ook Calvinistiese) terme gestel: as die mandator $D e i$, die na sy beeld geskape verteenwoordiger van God op aarde (Stoker, 1967: 55; Meeter, 1970:80-81). Indien die mens byvoorbeeld 'n boom plant en snoei, word dit "'n goddelike bestier/ na my manier" ("Hortologie", I:127). Cloete skryf in sy verse dat God die mens in sekere opsigte selfs "nodig" het: om die skeppingsdinge te bewaar en te kultiveer, maar ook om die wondere en samehang van die kosmos waar te neem en te (probeer) interpreteer ${ }^{12}$, asook daarvan te

12 Vergelyk die gedigte "ubiquiteit" (I:133-135), "Gaea" (Mdap:21-22) en "Eters 1" (Mdap 29) 
getuig ${ }^{13}$, veral indien sodanige mens gelowig is ${ }^{14}$.

Die digter (as kunstenaar) is syns insiens besonder geskik om die werklikheid op sodanige wyse te verken en te vertolk. Die digter is volgens hom "meer sensitief as die ander mense" (Cloete, 1994:6), sodat hy, veral indien hy 'n gelowige is, die fanerotiese aard van die skepping insien - byvoorbeeld hoe "bruin grond gloei van die hemel" ( $J: 103)$, of hoe "wat walg/ van mekaar (...) speels ingedeel (word)/ in mekaar deur die eksperimenterende Taksonoom" ( $J: 45)$. Bowendien: die wyse waarop die digter hom uitdruk, waarop hy "rym", dit wil sê "versoen", "korreleer" of "harmoniseer" (Cloete, 1994:7), maak hom vir hierdie taak geskik. Hy word sodoende "(d)eelgenoot" (D:34) van "God die digter" $(D: 49)$.

Hierdie "deelgenootskap" is 'n kunsteoretiese beskouing wat ten nouste met die sentrale tematiek van sy digkuns vervleg is. Taal en kuns, daarom ook die digkuns, is deel van die deur God geskape werklikheid, as vermoëns of gawes in die mens ingeskape, en vertoon as sodanig, ten spyte van die eiesoortigheid daarvan, korrespondensies met die res van die skepping. Cloete wil byvoorbeeld "amper sê dat die gedig self sy eie ingebore entelegie het, soos die mieliepit, die hoender en die sonneblom dit het" - iets wat hy "met 'n tweede stel oë insien" (Cloete, 1993b:10). Dié versentelegie is waarskynlik die "behoefte aan volmaaktheid" waarvan vroeër gewag gemaak is.

Kortom: die taal, die verstegniek en gedig- en bundelstrukture wat Cloete gebruik om sy ontdekkings aangaande die werklikheid weer te gee, eintlik ordenend te herskep, vertoon duidelike ooreenkomste met daardie waargenome werklikheid (-sdinge), en is dus ikonies ${ }^{15}$ daarvan. Dié feit word duidelik in die twee openingsgedigte van sy laaste bundel uitgespreek:

Die wonderlike om die wonderlike te kan skryf

is om met die taallaser te boetseer

en te fatsoeneer

tot taktiele lyf

$$
\text { ("Taallaser", Mdap:3). }
$$

In in die taal se meegewende lyf word deur die digter diep gevoelig ingegryf.

(Slotstrofe, "In-Skryf", Mdap:4.)

13 Vergelyk onder meer die gedigte "Gaea" (Mdap:21-23) en "goedweteronderhouer" (I:131)

14 Kyk "Esegiel" (Mdap 12) en "Insinjes" (Mdap 32)

is Vergelyk vorige artikels deur die artikelskrywer in hierdie verband (Odendaal, 1991:18$21 \&$ 1993:17-19) 
Op hierdie wyse voldoen die digter op 'n uitnemende wyse aan die vroeër genoemde gereformeerde roepingstaak om die (in geloof) waargenome wetmatighede cum Godsopenbaringe in die skepping te formuleer en te stel. Wanneer Stoker (1967:53) oor hierdie roepingstaak skryf, noem hy dat die stel van die skeppingswette 'n positivering daarvan behels, "soos byvoorbeeld geskied met die opstelling van kerkorde, of die stelling van staatswette, of die bepaling van die reëls vir omgang en verkeer". 'n Mens sou ten opsigte van die digterlike werkswyse van Cloete kon byvoeg: soos geskied deur die ikonisering van die samehang-in-verskeidenheid-verskynsel deur middel van die poëtiese tegniek.

\subsubsection{Die wonder en sinvolheid van die skepping}

In die lig van al bogenoemde is dit dan nie verrassend om te vind dat Cloete se waarneming en ervaring van die werklikheid gekenmerk word deur verwondering en 'n sinvolheidsbesef nie - aspekte wat, soos genoem, deur Stoker uitgesonder word as synde sprekend van die Calvinistiese belewing van die geskapene. Die seem wonder, en afleidings daarvan of samestellings daarmee, asook semanties verwante vorme soos toweragtig/betower/omgetoor, raaiselagtig, onverklaarbaar ensovoorts, kom byvoorbeeld meer as 90 keer in sy poësie-oeuvre voor. Opvallend is ook seme soos goed, gesond, slim en wys in sy gedigte, dikwels paradoksaal in verband met banale, pynlike of onvolmaakte dinge gebruik.

Cloete se hantering van die sonde- of kwaad-motief is tiperend van laasgenoemde. Cloete ervaar die bose of sondige in hoofsaak as 'n "vertekening" (om die titel van die tweede afdeling van sy bundel ldiolek - aangepas - aan te haal) van die oorspronklike Goddelike bedoeling, maar wat dan meermale tog as sinvol binne die Raadsplan van God voorgestel word16. Dit kom ooreen met die Calvinistiese siening van sonde en kwaad as "'n krenking en verwording", wat "tog nie 'n vernietiging van die oorspronklike sin van Gods skepping" beteken nie (Stoker, 1967:51).

\subsubsection{Die vreugde van die geskapene}

Gepaardgaande met die ervaring van die wonderbaarlikheid en sinrykheid van die skepping, is die belewing van vreugde in die aardse of kosmiese. Hierdie belewing van vreugde is ' $n$ religieuse ekstase wat spruit uit die ervaring van God se "neerbuigende genade" (Jansen van Rensburg, 1990:120-125) om Hom, in die

16 Die sondige en duiwelse verkry tog positiewe waarde binne die Raadsplan van God deurdat dit tot stigting dien. Bowendien: as uiting van die Goddelike bemoeienis met die mens in die skepping, word dit eintlik fanerosis, verkry dit 'n Goddelike openbaringsinhoud. 
aardse bestaan, aan die mens te openbaar en liefderyk aan die mens te steur. Dis 'n ervaring dus van God se "Geosentrie" en "Homosentrie", soos twee van sy gedigte $(A: 62 \& 67)$ heet; ook van die teenwoordigheid van die hemelse in die aardse, van die hiernamaalse in die hiermaalse.

Op eerste sig lyk dié beskouing nie te versoen met die Calvinistiese siening van die algehele verdorwenheid van die menslike toestand ná die sondeval nie. ${ }^{17}$ In die gedig "verlore seun" $(D: 95)$ verwerp Cloete dan ook tradisionele beskouings dat die aarde "'n anneks van die verderf" is en dat die hemelse nie daarin ervaar kan word nie. In die belangrike slotstrofe word die pad na God (metonimies met "alruin" en "seks") aangedui as die aardse en sinnelike:

(...) en tóé het ek pleks

van my behoorlik te bekeer

my oorgegee aan alruin en seks

en dáárlangs aangeland by die Here(.)

Die Calvinistiese siening is egter nie hiermaals-onvriendelik nie. Volgens Stoker (1967:55) mag die (gereformeerde) mens selfs uitroep: "Niks kreatuurliks (niks aards, wêrelds of kosmies) ag ek my vreemd nie en ek mag my in die skepping van God verheug en sal aan die skepping van God as Gód se skepping getrou bly!" En Jonker (1994:41) sê dat dit volgens Noordmans (1979) 'n “droom" van die gereformeerdes is "om iets meer van die koninkryk van God op aarde gerealiseer te sien". Dit is 'n strewe na die formatiewe en reformatiewe "Christianisering van die hele lewe" (Stoker, 1967:65-67), om - nie in eng godsdienstige $\sin$ nie, maar in ruimer religieuse $\sin$ - "'n God gehoorsamende aktualisering van alle moontlikhede wat God met Sy skepping en met die mens self aan die mens geskenk het", te bewerkstellig, "en wel tot eer en verheerliking van Hom wat die mens hiervoor bestem het".

Maar dit is tog wel iets anders as die felle aardse en lyflike ingesteldheid wat Cloete in sy poësie openbaar, die drif waarmee hy met al sy menslike vermoéns wil "prospekteer" in die geskapene omdat hy glo dat God Hom daarin openbaar en daarin teenwoordig is. Om maar ' $n$ enkele voorbeeld uit ' $n$ groot aantal moontlikhede aan te haal:

17 Die eerste van die sogenaamde "vyf stellinge van die Calvinisme" wat op die Sinode van Dordt (1618) aangeneem is ter herbevestiging van die standpunte van die Hervorming is die een aangaande die algehele verdorwenheid ná die sondeval. Dit verwys egter nie soseer na die toestand van die skepping nie, maar slaan eerder op die onvermoe van die mens om self iets tot sy verlossing by te dra, aangesien sy totale persoonlikheid en al sy vermoens - sy wil, begrip, hart - deur die sonde binnegedring is (Seaton, 1970:6-10). 
en daarin teenwoordig is. Om maar 'n enkele voorbeeld uit 'n groot aantal moontlikhede aan te haal:

(...) ek gaan draal

in die nuwe bekende uithoek

oor sy brîe in sy strate lewe

met oorleg en beoefen my asemhaal

geraffineer ek gaan soek

God lewend en leef oordrewe

("leeglê", $A l: 122$ ).

Daar is by Cloete selfs 'n uitgesproke vereenselwiging met die natuurdinge. Vergelyk:

ek word al meer

julle tarentaal

njala

en ander familie

met julle konformeer

ek met my bas- en blaar- en mier-

water- aarde- dier-

en ander patie

$$
\text { ("naturalis", } D: 57) \text {. }
$$

\subsection{Motiewe in Cloete se poe̊sie wat afwyk van die Calvinistiese beskouinge}

\subsubsection{Kosmiese immanensie van 'n transendente God - of panenteïsme?}

Die Calvinisme, wat aanspraak maak op 'n konsekwent Skriftuurlik gefundeerde beskouing, huldig 'n teïstiese lering aangaande die verhouding van God en kosmos. Hiervolgens word 'n radikale en absolute onderskeid tussen die Goddelike aard en die kosmiese aard getref. Die siening word gehandhaaf "dat niks van God kosmies is, en niks van die Kosmos in wesentlike sin goddelik is nie" (Stoker, 1970:13). Hoewel God in hierdie sin as absoluut transendent bo die kosmos beskou word, word egter aanvaar dat $\mathrm{Hy}$ weens sy alomteenwoordigheid, onderhouding en bestiering tegelyk ook immanent in die kosmos is. Dit beteken nie dat Hy as identies met die kosmos gesien word nie (Stoker, 1970:13).

Dit is hierdie immanensie van God in die kosmos wat Cloete so sterk ervaar en deur sy woordkuns wil laat blyk. Vergelyk maar net die volgende:

Ametropies tussen groot ligballe

kan ons Hom nie gewaar

waar Hy ontelbaar in getalle

tel nie. Stekelige sterre in die swerk 
flikker waar ligjare uitmekaar

Hy spelenderwys verdiep in swart heelalgate werk

("Suidpool en senit II", $A: 2$ ).

God laat Hom in in die klank

van ons taal resitatief ingeweef of tenoor

hoog. Almal wat kan praat en sing

kan Hom inpraat, kan goddank dank-

en prysliedere dans ...

$$
\text { (“Ps. 150", I:79). }
$$

Soms lyk dit egter of Cloete se ervaring van die immanensie van God in die kosmos oorgaan in 'n panenteïstiese ${ }^{18}$ Godsbeskouing - dat hy aan die skeppingsdinge 'n Goddelike aard wil toeskryf. Vergelyk:

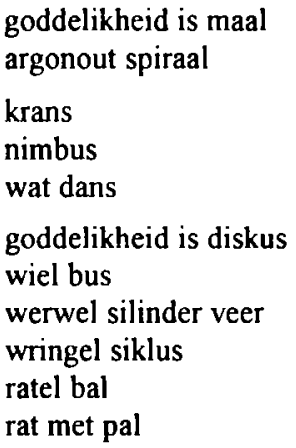

("holofrase", $I: 118$ ).

Die panenteisme is een van die sogenaamde sintese-beskouinge ${ }^{19}$, dit is beskouinge wat die teëstellinge tussen God en kosmos wil verklein of relativeer. Dié sintese-beskouinge word pertinent in die Calvinistiese teologie verwerp (Stoker, 1970:15-17).

\subsubsection{Die eiesoortige mistiek in Cloete se poësie}

Die vraag na die Calvinistiese aard van Cloete se beskouinge word voorts gekompliseer deur 'n duidelike mistieke trek in sy poësie. Trouens, soos ek

18 Waar 'n panteistiese beskouing daarvan uitgaan dat "everything is God", glo die panenteis "God is really in everything" (Inge, 1921:179).

19 Stoker (1970:11-15) gee 'n insiggewende skematiese indeling van die leringe oor die verhouding God en kosmos wat weens ruimtebeperkinge nie hier aangehaal kan word nie 
voorheen aangevoer het (Odendaal, 1993:1-23), kan gesê word dat sy ganse poësie-oeuvre eintlik in die teken van 'n eiesoortige mistiek staan.

\subsubsection{1 'n Aardse, lewensdriftige mistiek}

'n Aardse, lewensdriftige mistiek is 'n mistiek wat wars staan van die tipies Middeleeuse, asketies geïnspireerde mistieke tradisie, en wat eerder aansluit by latere ontwikkelings wat die omwêreld nie meer ervaar as iets wat skeiding maak tussen die mistikus en die godheid nie, maar as "'n manifestasie van die vermoë en liefde van die godheid en 'n bevestiging van sy alomteenwoordigheid" (Olivier, 1985:65). Om hierdie rede, so is in die genoemde artikel aangedui (Odendaal, 1993:3-4), is die mistieke ervaring gekenmerk deur vreugde en 'n allesomvattende liefde, is dit 'n belewenis van die sinrykheid en samehang van die kosmos, en terselfdertyd van 'n tydruimtelike uitgebreidheid.

In 'n hele aantal gedigte uit sy oeuvre, veral in latere bundels soos Driepas (met die sprekende motto "a humble love of earthly and divine things") en Met die aarde praat, word presies diè soort ervaring redelik eksplisiet uitgedruk. Vergelyk:

... En altyd is daar lig wat áfstraal in die liefs klein afgemete vertrek, corvloedig, uit die oop grote universum en wat die klein aardse geslote stilte in die onmeetlike laat asemhaal

("Vroue van Vermeer", D:38).

Vir ons was dit opwinding om besadig in die verborgene woordeloos te voel

hoe alles van lig versadig raak en alles en alle sterre saam afkoel.

Die nietige het ons rykdom geword, die daaglikse het sin gekry omdat ons van die datumlose begin begin weet het en van die datumlose wat kom

(“Opruim", Mdap:96-99).

Bosman (1989:298-299) skryf na aanleiding van 'n onderskeid wat sy tref tussen die Rooms-Katolieke mistiek en die sogenaamde Protestants-Christelike mistiek dat die intellektuele inslag van Cloete se poësie "nie pas in die tradisie van die mistiek waar rede moet plek maak vir 'n blinde geloof en gerigtheid op die liefde van God nie". Dié digter "se voortdurende bewus-wees van die groot samehang en sy intense betrokkenheid by sy omwêreld", asook sy gevolglike "vreugde oor en liefde vir die ganse skepping", onderskei hom volgens haar eerder as 
Protestantse mistikus, in teenstelling met die Rooms-Katolieke mistieke tradisie wat "volkome onthegting van medemens en omgewing vereis". 20

Wat die mistiek in Cloete se poësie 'n eiesoortige skakering gee - so is voorheen reeds aangevoer (Odendaal, 1993:9-16) - is die intense aardsheid, sintuiglikheid en selfs sinlikheid daarvan, wat ook neerslag vind in 'n felle erotiek en 'n lewendige aktualiteit. Die panenteïsties-georiënteerde aard van sy Godsbeskouings laat hom op hierdie wyse, en nie deur middel van 'n transendente strewe nie, uitreik na ' $\mathrm{n}$ vereniging met die in alles rondom hom geopenbaarde God.

\subsubsection{2 'n Calvinistiese mistiek?}

Dit bly egter steeds ' $n$ vraag hoe Calvinisties en Christelik sodanige mistiek is. Olivier (1985:5) en Heyns (1982:101) meen dat die strewe van die mistiek na eenwording met God - in tradisionele sin deur wêreldversaking en toespitsing op die kontemplatiewe lewe - wesenlik vreemd staan teenoor die (Calvinisties-) Christelike belydenis dat alleen die soenverdienste van Cliristus dit vir die deur sonde gekorrupteerde mens moontlik maak om persoonlike kennis van en 'n persoonlike verhouding met God te hê. In die lig hiervan val dit op dat, soos voorheen aangetoon is, daar maar enkele kere pertinent na Christus verwys word in Cloete se gedigte, en dat verwysings na die Ou Testament daarin oorheers.

Soos reeds gesê is, is Cloete se mistiek egter nie van die tradisionele soort nie: dit is aards en aktueel. Myns insiens moet dit as 'n soort estetiese mistiek beskou word, dit wil sê as 'n soort onmiddellike, primordiale Godsbelewing wat via die sintuie en die affekte ingegee word, maar wat dan ook met 'n kognitiewe element gepaard gaan (vgl. Odendaal, 1993:14-16).

\subsubsection{Die Christus-gegewe in die lydingsmotief}

Die weinige aantal kere dat die naam van Jesus Christus in Cloete se poësieoeuvre genoem word, laat ' $n$ mens miskien die belangrikheid van die Christusgegewe in sy denkraamwerk onderskat. 'n Bestudering van die lydingsmotief in Cloete se digkuns maak dit duidelik.

20 Laasgenoemde is byvoorbeeld die rede waarom die Katolieke digter Guido Gezelle dit aanvanklik so moeilik gevind het om sy ervaring van natuurgenot te versoen met die hunkering na mistieke eenheid met God (vgl. onder meer Jonckheere, 1988:253)

Daarteenoor kan Meeter (1975:60-62) aangehaal word waar hy beweer dat die "proper balance" wat gehandhaaf word tussen "seemingly logical opposites", waaronder intellektualisme en mistisisme. juis een van die uitstaande kenmerke van die Calvinisme is. 
Vanweë die digter se eie herhaaldelike siekte-ervarings is pyn en lyding 'n belangrike motief in sy digkuns (vgl. onder meer Cloete, 1993a:7). In OudTestamentiese figure soos Jakob, Hiskia, Dawid en veral Job vind hy parallelle vir die wyse waarop hy in sy eie lyding die genadige bemoeiing van God beleef. Christus se lyding, liefdevol gewil deur God ter wille van die mens, is intertekstueel en religieus egter die prototipe van dié openbaringswyse van die Goddelike liefde (vgl. Jooste, 1995:106). Byvoorbeeld: net na die (humorvolle) gedig "versiening" in Allotroop (Al:90) waarin die ondraaglikheid van die pyn uitgespreek word, volg die gedig "emmaus" $(A l: 91)$ waarin gesuggereer word21 dat die simpatieke teenwoordigheid van Christus juis ervaar word in die uur van uiterste lyding:

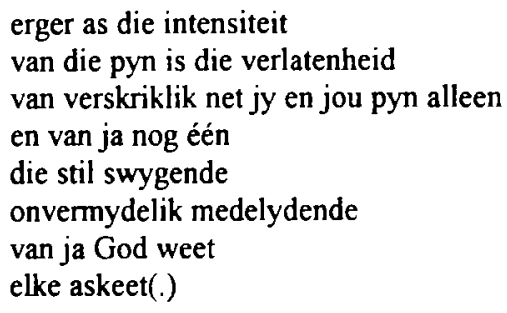

In meer as een gedig (byvoorbeeld "meelyfvoel", "kwietis" en "instaan", Al:35, $36 \& 42$; "uitpraat" en "Koerantberig", $D: 45$ \& 163-164) word geïmpliseer dat die mens juis deur lyding die Goddelike deelagtig kan word of die liefdevolle lyding van Christus kan snap. Vergelyk:

\section{(...)}

hou aan aanhoor

(...)

... van die dood

van honger bly opskryf bly invryf

in die groot liggaam om mee te voel aan Eén Lyf

("meelyfvoel", $A l: 35$ )

\subsubsection{4 'n Inkarnatoriese soteriologie}

Jansen van Rensburg (1990:126-127) noem dat die gedagte van 'n "mistieke" eenwording met Christus (die genadige deelhê aan sy sterwe en opstanding) nie so vreemd aan die Christelike geloofsleer is nie, en dat dit ' $n$ wesenlike deel van

21 Ook via die verwysing na die Bybelse verhaal aangaande die Emmausgangers wat moes ontdek dat die onbekende wat hulle vergesel het, eintlik die opgestane Jesus was (Luk. 24:13-35). 
die soteriologie 22 is. Die soteriologiese opvattings van die Oosterse en Westerse Christelike kerke verskil egter ingrypend; vorm trouens die kern van die breuk tussen hierdie twee kerke (Jonker, 1994:21). Die Westerse kerk dink hamartiosentries (sondegerig), en die vleeswording van Christus is vir hierdie kerk belangrik met die oog daarop dat Christus as Middelaar deur sy kruisdood en opstanding verlossing van die sonde bewerk het. Hierteenoor dink die Oosterse kerk inkarnatories, sodat die vleeswording van Christus volgens dié kerk die menslike natuur en die hele werklikheid tot gemeenskap met God verhef het.

In gedigte soos hierbo aangehaal, openbaar Cloete myns insiens 'n neiging tot sodanige inkarnatoriese denke.

\subsection{Die probleem van die verganklikheid in Cloete se poësie}

Die groot teenstrydigheid in dié skepping waarin Cloete die teenwoordigheid van God ervaar, is die verganklikheid, veral die menslike sterflikheid. Hy beskryf die dood sterk negatief, byvoorbeeld as "die gruwelike uiteindelike skande" (Al:73) of as "die walglik banale cliché" ( $A l: 85)$.

'n Sekere beheptheid met die dood in sy poësie is die gevolg hiervan (Bosman, 1989:247). In ongeveer 'n honderd gedigte, versprei deur sy oeuvre, hou hy hom besig met verganklikheid en sterflikheid. In byna die helfte van die gevalle is daar sprake van of 'n (vergeefse) verweer/stryd daarteen, of 'n wens om die uitstel van die dood, of ' $n$ bepaalde opstandigheid daaroor.

\subsection{1 'n Onvrede met die sterflikheid en 'n tweeslagtige, gedempte heilsperspektief}

In dié verset is die enigste tekens van onvrede met die Goddelike bestel in Cloete se gedigte te bespeur. Dit is veral in sekere gedigte uit Jukstaposisie en Allotroop die geval. Die verganklikheid word gesien as iets wat alles aards, die dinge waarin die digter so 'n behae het, tevergeefs maak ("Prediker", $J: 33$ ). Selfs die al hoe weerbaarder makende pyn word in 'n sekere sin uiteindelik daardeur sinneloos gemaak: die "leergelooide" mens, wat "al hoër en hoër leer ... om hom te verweer ... tuimel taai neer" as antiklimaks in die dood ("Parabool", $A: 52$ ).

Dit val ook op dat die gelowige Cloete se heilsperspektief op die hiemamaals redelik tweeslagtig, en eintlik relatief gedemp is - gesien in vergelyking met die vreugde wat in die aardse bestaan gevind word. Die aardse bestaan met sy teenstellende ervarings van vreugde en pyn word ' $n$ aantal kere pertinent verkiesliker voorgestel as "'n geïdealiseerde (volgens gangbare religieuse op- 
vattings) toekomstige bestaan sonder pyn en lyding" (Gräbe, 1984:96). Op sy siekbed lê hy byvoorbeeld en "beraam herstel", want die hemel is hol/ en koud en ver ("lê en roer", $A l: 48$ ). Nog één voorbeeld: Net nadat van die ernstige siekbed herstel is, is daar 'n oproep aan die gesinslede om "in ons mou" te lag, want "die hemel is uitsluitend hemelsblou" ("oopooggebed aan ontbyttafel", $A l: 137)$. Die feit dat die hiemamaalse dus (tydelik) uitgestel is, bring 'n soort ongeoorloofde vreugde.

So 'n visie van 'n skrikwekkende, koue en verre hiemamaals lyk of dit die tradisioneel-Christelike, maar ook Calvinistiese vreugdevolle heilsverwagting weerspreek. Die hiermaalse en hiemamaalse staan volgens die Calvinistiese siening nie teenoor mekaar nie. Die Calvinis se vreugdevolle belewing van die skepping en die aardse geskied in die lig van die vreugdevoller wete dat die hiernamaalse werklikheid 'n herskepte werklikheid of 'n herstelde geskape werklikheid sal wees, 'n nuwe aarde waarmee die nuwe hemel verenig sal wees (Jonker, 1994:43; Stoker, 1967:55).

\subsection{2 'n Aanvaarding - sonder volkome begrip}

Tog is daar ook 'n keersy aan Cloete se beskouing van die dood. Daar is eerstens ' $n$ nugtere besef van die onvermydelikheid daarvan. ${ }^{23}$ Voorts word die dood/ verganklikheid by geleentheid ook as "goed" (Al:96) en "sinvol" (D:179) bestempel

In 'n gedig soos "sononder" (Al:124) verkry hierdie beskouing van dood en verganklikheid in die eerste plek 'n positiewe waarde deurdat die ervaring van die hemelse in die tydelik-aardse die toekomstige hemelse na iets begeerliks laat lyk - 'n siening wat dus strook met die Calvinistiese soos hierbo uiteengesit. In dié gedig ry die spreker "deurdringend van die ondergaande/ son af weg ooswaarts singend", waar daar onder meer "'n reënbooggloor (...) diepoog ingloei" simbolies dus weg van die dood af na die nuwe lewe toe, deur die reënbooggegewe geskakel met die genadeverbond van God met Noag ná die sondvloed (Gen. 9). Die reis gaan deur 'n paradysagtige landskap gekenmerk deur vrugbaarheid, oorvloedige lewe, vreugde en skoonheid, en deurgaans word beklemtoon hoedat dit in 'n "goue poeier/ tasbare lig" gehul is. Die landskap is as't ware 'n voorspel tot die hemelse self - of dan: beeld in terme waarvan die hiemamaals verstaan word. 24

23 Vergelyk onder meer $A l: 87, D: 136 \& 137$. Teenoor die besef dat "(a)lle snye groei" (Al.94), staan die insig: "groei gaan sterf" $(D: 136)$

24 Beukes (1989:142-169) skryf uitvoerig oor hierdie gedig. Bosman (1989:285) skryf meer spesifiek oor die son-simboliek in dié gedig. 
Aan die ander kant word die kosbaarheid van die gewone en selfs banale dinge in die aangesig van die dood soveel sterker beleef. ${ }^{25}$ Ook verkry die dood soms waarde as instrument waarmee God Hom met ons bemoei tot ons eie heil ${ }^{26}$, of waar die dood as die groot ontdoener van menslike ydelhede en pretensies voorgestel word ${ }^{27}$ Die dood stroop die mens af tot die essensiële, ontwaar hom van alle onegte "waardigheid of enige só-heids" ("Ontwaarding", D:90).

Daar is ' $n$ breë groei in Cloete se oeuvre te bespeur vanaf eerstens 'n weerstand teen en 'n opstandigheid oor, tot tweedens 'n aanvaarding van die verganklikheid as deel van die Goddelike bestel. Tot en met ongeveer die helfte van sy derde bundel (bladsy 80 van Allotroop), en veral in Jukstaposisie en die eerste helfte van Allotroop, is eersgenoemde oorheersend; van daar af, en toenemend in Driepas en Met die aarde praat, laasgenoemde.

Die wendingspunt is in die gedig "Allofrasie" (Al:81-83). Dié gedig, geskryf na aanleiding van die dood van 'n geliefde seun ${ }^{28}$ en in briefvorm gerig aan hom, beskryf met ironiese ondertone die moeilike proses om die leed by die afsterwe van ' $n$ geliefde te verwerk. In die tweede laaste strofe gee die spreker in terme van die gewelddadige dood van die oorledene (hy het klaarblyklik in 'n motorongeluk gesterf) ' $n$ vooruitblik op hoe die agtergeblewenes die dood aan eie lyf gaan voel. Dié strofe word omgrens deur twee reëls waarin die liefde sentraal staan:

(...) Sonder Die liefde is die dood oorbodig (sic).

en

Nooit had só baie jou só lief soos in jou kis nie ...

Die onderskeie beklemtoningswyses in dié reëls onderstreep die belangrikheid van die liefdesmotief.

Die slotreël van die gedig lui dan:

(...) Jy ignoreer

ons maar jy weet nie wat jy jammerlik mis nie.

25 Vergelyk: $A l: 59,63,108 \& 121 ; D: 182-185 ;$ Mdap $86,87,88,92-93$ \& 96-99.

26 Vergelyk: Al:101 \& 114; D:163-164.

27 Vergelyk: $A: 17,54 \& 55, J: 18,64,83 \& 86 ; A l 74,77.78 \& 79, I: 86 ; D: 90 \& 135$.

28 Volgens sekere bronne die digter se skoonseun - vgl. Viljoen, L. (1995b:99). 
Die mistieke groot bruis, die beroerde gewemel om jou sonder jou. Sien jou in die hemel.

Die liefde wat die agtergeblewenes vir die oorledene voel, staan geprojekteer teen die liefde van God; 'n mistieke eenwording met die Transendentale word gesuggereer ("mistieke groot bruis"). Die implikasie is dat die Goddelike liefde die dood vergesel, dat die gestorwene in Goddelike liefde begelei en ontvang is in die sterwensproses (net soos die deur God aangesproke sterwende later in dieselfde bundel in die gedig "in memoriam lenie", $A l: 101$ ). Daarom kan met troos uitgesien word na die wederontmoeting in die hiernamaals: "Sien jou in die hemel."

In 'n hele aantal gedigte hierna in Allotroop (103, 104, $107 \& 131-134)$ word 'n aanvaarding van die Goddelike wil in hierdie verband gesuggereer of redelik direk uitgespreek. Vergelyk:

(...) Hy tel ons maar Hy tel of weeg anders as ons. Net wat ons mág en kán dink vertel Hy. Ook hoe en dát ons sterf is vir Hom lewe werd (“Ons", Al:134).

Ook in die latere bundels is sulke uitsprake te vinde. Byvoorbeeld:

Sodra Hy van die aardse vreugde moeg raak, breek Hy sy wonderbaarlike ligsnoer van son en planete, het Hy genoeg daarvan, roer Hy dit in 'n nuwe moer in waar Hy nuwe stelsels sonder ons voeg (“Draal", $D: 183$ ).

Soms grens Cloete se opvattings in hierdie opsig ook aan die inkarnatoriese van die Oosterse Christelike kerk. Waar die verlossing in Jesus Christus deur die Westerse kerke (hamartiosentries) vertolk word as ' $n$ verlossing van die sonde, sien die Oosterse Christelike kerk verlossing primêr as 'n verlossing van die dood en verganklikheid (Jonker, 1994:20-21). Ek haal ter stawing uit slegs één gedig van Cloete aan - een wat hy geskryf het (Cloete, 1993a:7) nadat hy in die tagtigerjare weens siekte in die grootste lewensgevaar was en toe weer herstel het:

één keer moet ek verloor en finaal maar daarvóór kort en kosbaar hoor 
hy my gun hy my dit dat ek nog in die son kan sit sien hoe maak die maan die nag wit

voor die lig uit my glip soen ek bloed uit die klip met 'n warm teer lip

die passie prakseer

'n effektiewe verweer

teen die dood dalk nog net één keer

("outo-immunisering", $A l: 108$ ).

Die verwysing na die bloed wat uit die klip gesoen word in die voorlaaste strofe, konnoteer onmiskenbaar die soendood van Christus aan die kruis wat in liefde aangegryp word, terwyl die "passie" waarvan in die slotstrofe melding gemaak word, dubbelsinnig heenwys na lewensdrif aan die een kant, maar ook na die lyding van Christus as "effektiewe verweer/ teen die dood" aan die ander kant.

Daar is by Cloete dus beslis 'n aanvaarding van die Goddelike bestel met betrekking tot die dood, hoewel hy weens "(s)wak oë" (D:174) eintlik nie voorbereid voel "vir die sneeuende lig van die suiwer antarktika,/ vir die ewigheid van die rein heelheid" nie. Daar is aanvaarding in geloof, hoewel nie met volkome begrip nie. Daarvoor is die skepping en lewe - waarin God sy genadige liefdevolheid laat blyk; trouens panenteisties selfs teenwoordig is - vir hom té wonderbaarlik.

\section{Ten slotte}

In 'n oorsigtelike vergelyking van die wyses waarop onderskeidelik Totius en Cloete die pyn- en doodsmotiewe hanteer, het Bosman (1989) tereg bevind dat 'n mens nie in hierdie opsig die eenvoudige, beskeie soort aanvaarding van die Goddelike wil by Cloete aantref soos by die streng Calvinistiese Totius nie. Volgens haar is Cloete "se vergestalting van dieselfde ervaring meer erudiet en genuanseer, vrymoediger en die uitdrukking van 'n meer spontane verhouding met God" (Bosman, 1989:286), waardeur sy benadering tot God "tipies van die jonger digtergeslag" is (Bosman, 1989:228).

In hierdie opsig vertoon Cloete se verse eerder raakpunte met dié van die Katolieke digteres Sheila Cussons, wie se spontane en vertroulike omgang met God en God in die dinge (vgl. Bosman, 1989:299-300), ook die mees banale dinge, aansluit by die mistieke tradisie van die dertiende- en veertiende-eeuse Hadewych, Ruusbroeck en Luyken (Kannemeyer, 1983:198).

Sy herhaalde ervarings van pyn en siekte, tot byna sterwens toe, het die wonder en vreugde van lewe, die liggaam, sy sintuie en drifte, asook die genotvolle van 
die skeppingsdinge wat byna panenteïsties in die Goddelike opgaan, by Cloete akuut gemaak. Dit voer sy Calvinistiese beskouings aangaande die vleeswording van Christus tot aan die grens van die inkarnatoriese van die Oosterse Christelike kerk. Dit laat hom nié uitsien na die hiernamaals nie; laat hom die dood trouens as iets baie negatiefs ervaar.

\section{Bibliografie}

Beukes, M.P. 1989. Vooropstelling, kohesie en koherensie in die poesie van T.T. Cloete Potchefstroom : PUCHO. (M.A -verhandeling.)

Bosman, ME. 1989. Op Hom die groot hosannas: Enkele aspekte van die moderne Christelike poesie in Afrikaans. Grahamstad : Universiteit Rhodes. (D.Litt.-proefskrif.)

Botha, D. (samest.) 1991. In ons goeie boekies. Skrywers en redakteurs oor Tafelberg. Kaapstad : Tafelberg.

Brink, A.P. 1981. Poèsie 1980: Swaarweer en kleinwind. Standpunte 154, 34(4):29-45, Augustus

Cloetc, T.T. 1988. Die boek wat laaste uitgepak word: oor die Bybel en die Afrikaanse digkuns. (Lesing gelewer in Julie op uitnodiging van die C.B. Powell-Bybelsentrum, UNISA, Pretoria.) Ongepubiseerde notas met bladsye genommer van 19-50 in besit van en aangehaal deur Jooste, E. 1995.

Cloete, T.T. 1991. Waarom skryf, en publiseer? In: Botha, D. (samest.). In ons goeie boekies. Skrywers en redakteurs oor Tafelberg-Uitgewers. Kaapstad : Tafelberg. p. 2540.

Cloete, T.T. 1993a. Profiel van T.T. Cloete: 'Die gedig is ek'. SWO Bulletin, 5(6):6-7, Julie.

Cloete, T.T. 1993b. Die gegewens van my poesie. Manuskrip: Voordrag, UNISA, Biblioteek- en Inligtingskunde, 17 Junie

Cloete, T.T. 1994. Die digter se omgaan met die werklikheid. Ensovoort, 6(1):6-7.

Glicksberg, C.I. 1977. Literature and Religion. Westpon, Conn. : Greenwood Press.

Grabe, I. 1984. (Resensie van) Jukstaposisie (T.T. Cloete). Tydskrif vir Letterkunde, 22(1):93-96, Februarie.

Grové, A.P. 1995. Stemme uit die grot. (Resensie oor Troglodiet van Tom Gouws.) Insig: 32 , Oktober.

Hambidge, J. 1995. Vergeet tog die vadere (Resensie oor Kontrafak van Johan Myburg.) Insig: 37, April.

HAT

$K y k$

Odendal, F.F. (hoofred.) 1994. Verklarende hantwoordeboek van die Afrikaanse taal $(H A T)$. Derde hersiene uitgebreide uitgawe. Midrand : Perskor Uitgewery

Heyns, J.A. 1982. Teologiese etiek. Pretoria : N.G.-Kerkboekhandel.

Inge, W.R. 1921. Studies of English Mystics. London : John Murray

Jansen van Rensburg, J.H. 1990. Die jukstaponering van hemel en aarde in die poèsie van

T.T. Cloete. Potchefstroom : PUCHO. (M.A.-verhandeling.)

Jonckheere, W.F. 1988. Periode van vernuwing en idealisme In: Van der Elst, J. (hoofred.). Momente in die Nederlandse letterkunde. Pretoria \& Kaapstad : Academica. p. 239-318.

Jonker, W.D. 1994 Bevrydende waarheid. Die karakter van die gereformeerde belydenis. Wellington : Hugenote-Uitgewers

Jooste, E. 1995. Idjolek van T.T. Cloete. Literator, 16(3):103-132, November. 
Kannemeyer, J.C. 1983. Geskiedenis van die Afrikaanse literatuur 2. Pretoria/ Kaapstad/ Johanneburg : Academica.

Lindenberg, E. 1995. Te veel Cloete, Opperman? (Resensie oor Kontrafak van Johan Myburg.) De Kat: 116, Julie.

Literator (spesiale nommer opgedra aan T.T. Cloete), 16(3), November 1995

Meeter, H.H 1975. The Basic Ideas of Calvinism. Vyfde, hersiene uitgawe. Grand Rapids, Michigan : Baker Books House.

Nienaber, C.J.M. 1983. Cloete en vliegtuigie op handjie. Standpunte 163, 36(1):56-64, Februarie.

Noordmans, O. 1979. Het Koninkrijk der hemelen. In: Verz. Werken II. Nijkerk : Callenbach.

Odendaal, B J. 1991. Sien (en hoor!) is glo: 'n voorlopige verkenning van ikonisiteit as retoriese strategie aan die hand van twee kort gedigte. Literator, 12(3):13-23, November.

Odendaal, B.J. 1993. Via alruin en seks tot God: die eiesoortige mistiek in die poesie van T.T. Cloete. Literator, 14(2): 1-23

Odendaal, B.J. 1995. Gouws se tweede bundel toon belofte van digterskap. (Resensie oor Troglodiet van Tom Gouws.) Die Volksblad: 8, Des. 4.

Odendal, F.F. (hoofred.) 1994. Verklarende handwoordeboek van die Afrikaanse taal (HAT). Derde hersiene uitgebreide uitgawe. Midrand : Perskor Uitgewery.

Olivier, F. 1980. Die Afrikaanse poësie van vandag. Standpunte 150, derde reeks 33(6):2530, Mei.

Olivier, S.P. 1985. Mistiek in die Afrikaanse poesie. Potchefstroom : PUCHO. (D Litt proefskrif.)

Opperman, D.J. 1991. Keurdersverslag: Angelliera. In: Botha, D. (samest.). In ons goeie boekies. Skrywers en redakteurs oor Tafelberg-Uitgewers. Kaapstad : Tafelberg. p. 41 42.

Potgieter, S. 1988. Orde en ordelikheid in Idiolek van T.T. Cloete. Klasgids, 23(1):6-9, Februarie.

Pretorius, R. 1981. Angelliera. van twee kante bekyk. Tydskrif vir Letterkunde, 19(2):7783, Mei.

Schutte, H.J. 1984. 'n Poètika van korrespondensies: Angelliera en Jukstaposisie. In: Viljoen, H., Gräbe, I., Jooste, E. \& Steenberg, D. (reds.). In teen die groot vergeet. Potchefstroom : PUCHO. p. 93-107.

Seaton, W.J. 1970. Die vyf stellings van Calvinisme. (Afrikaanse uitgawe 1980.) Kaapstad N.G. Kerk-Uitgewers.

Spies, L. 1984. Geloof en gedig in die Afrikaanse poèsie van Sewentig. Ensovoort, 4(1) 2528, Mei.

Stoker, H.G 1967. Oorsprong en rigting, Band I. Kaapstad : Tafelberg

Stoker, H.G. 1970. Oorsprong en rigting, Band 2. Kaapstad : Tafelberg.

Van Zuydam, S.W. 1995. Vaardiger en ryper digter aan die woord. (Resensie oor Kontrafak van Johan Myburg.) Die Volksblad: 8, Mei 1.

Viljoen, H. 1995a. Die fenomenologie van T.T. Cloete. Literator, 16(3):43-60, November.

Viljoen, L. 1995b 'n Retoriese analise van die vyf lykdigte in T.T. Cloete se Allotroop. Literator, 16(3):81-103.

Visagie, J.A.G. 1986. T.T. Cloete as eksponent van die moderne Afrikaanse poësie soos hy dit self gekarakteriseer het in Die Afrikaanse literatuur sedert sestig Pretoria : UNISA. (M.A.-verhandeling.) 
